\title{
Cave finds indicate elk (Alces alces) hunting during the Late Iron Age in the Bavarian Alps
}

\author{
Kerstin Pasda ${ }^{1}$, Matthias López Correa ${ }^{2,3}$, Philipp Stojakowits ${ }^{4}$, Bernhard Häck ${ }^{5}$, Jérôme Prieto ${ }^{6}$, \\ Najat al-Fudhaili ${ }^{2}$, and Christoph Mayr ${ }^{6,7,8}$ \\ ${ }^{1}$ Institute of Pre- and Early History, Friedrich-Alexander-Universität Erlangen-Nürnberg, \\ Kochstr. 4/18, 91054 Erlangen, Germany \\ ${ }^{2}$ GeoZentrum Nordbayern, Friedrich-Alexander-Universität Erlangen-Nürnberg, Loewenichstr. 28, 91054 Erlangen, Germany \\ ${ }^{3}$ Istituto di Scienze Marine, Consiglio Nazionale delle Ricerche, via Gobetti 101, 40129 Bologna, Italy \\ ${ }^{4}$ Institute of Geography, Universität Augsburg, Alter Postweg 118, 86159 Augsburg, Germany \\ ${ }^{5}$ Bayerisches Landesamt für Denkmalpflege, Hofgraben 4, 80539 München, Germany \\ ${ }^{6}$ Palaeontology \& Geobiology, Ludwig-Maximilians-Universität, Richard-Wagner-Str. 10, 80333 München, Germany \\ ${ }^{7}$ Institute of Geography, Friedrich-Alexander-Universität Erlangen-Nürnberg, Wetterkreuz 15, 91058 Erlangen, Germany \\ ${ }^{8}$ GeoBio-Center, Ludwig-Maximilians-Universität München, Richard-Wagner-Str. 10, 80333 München, Germany
}

Correspondence: Kerstin Pasda (k.pasda@mail.de)

Relevant dates: $\quad$ Received: 11 May 2020 - Revised: 12 August 2020 - Accepted: 26 August 2020 Published: 21 October 2020

How to cite:

Pasda, K., López Correa, M., Stojakowits, P., Häck, B., Prieto, J., al-Fudhaili, N., and Mayr, C.: Cave finds indicate elk (Alces alces) hunting during the Late Iron Age in the Bavarian Alps, E\&G Quaternary Sci. J., 69, 187-200, https://doi.org/10.5194/egqsj-69-187-2020, 2020.

Abstract:

The finding of a partially preserved elk skeleton from the Bavarian Alps is reported. Remnants of an adult male were found, together with skeletal elements of juvenile moose calves, at the base of a talus cone in the pit cave Stiefelschacht, next to Lenggries (southern Germany). The adult's bones exhibited anthropogenic traces like cut marks and were radiocarbon-dated to the Late Iron Age. A projectile hole in the left shoulder blade and cut marks on the bones are indicative of hunting and meat usage. The elk remains were associated with several wild and domestic species such as ungulates and hare but were not, however, accompanied by archaeological artefacts. Other archaeological sites of the Late Iron Age are so far not known within a distance of less than $30 \mathrm{~km}$ to the Stiefelschacht. While the presence of elk during prehistoric times in the Alps has already been known before, the finds and the location are unique in that they are the first evidence of elk hunting during the Late Iron Age in the northern Alps.

Kurzfassung: $\quad$ Der Fund eines Elch-Teilskeletts aus den Bayerischen Alpen wird beschrieben. Neben diesem adulten männlichen Tier wurden Skelettelemente von Elchkälbern am Fuß eines Schuttkegels in der Schachthöhle Stiefelschacht bei Lenggries (Süddeutschland) entdeckt. Eine Radiokarbondatierung lässt eine Alterseinstufung des Elchs in die späte Eisenzeit zu. Ein durch ein Projektil verursachtes Loch im linken Schulterblatt und zahlreiche Schnittspuren auf den Knochen verweisen zudem auf einen anthropogenen Zusammenhang. Weitere Knochenfunde in der Höhle umfassten einige wildlebende und domestizierte Tierarten, jedoch waren keine archäologischen Funde mit den Knochen assoziiert. Die bisher bekannten eisenzeitlichen Siedlungen befinden sich in einer Entfernung von 
mehr als 30 Kilometern zu der Schachthöhle. Sowohl die Fundsituation als auch die Fundlage sind bisher einmalig, da sie erstmals Elchjagd in der späten Eisenzeit in den nördlichen Alpen belegen.

\section{Introduction}

Bone findings suggest that elk (Alces alces) were present at least since the Late Glacial in the northern Alps, but osteological evidence ends in medieval times (Schmölcke and Zachos, 2005; beginning of the early medieval period approx. 5th century-approx. 15th/16th century CE; Sommer, 2006). In southern Germany, the latest reports of skeletal remains south of the river Danube are from the Iron Age (Schmölcke and Zachos, 2005; Iron Age approx. eighth-first century BCE; Sommer, 2006). In Roman times (approx. first century BCE-fifth century CE, Sommer, 2006), elk apparently were still present in the Alps, as documented by the historian Strabo citing Polybius (Woodburn Hyde, 1918). Although reports of sightings during the last decades prove that elk still appear occasionally in north-eastern Bavaria (LWF, 2011) and extra-Alpine Austria (Steiner, 1995), they remain extinct in the Alps since medieval times (Schmölcke and Zachos, 2005). However, the regional distribution of elk in Bavaria and timing and causes of their extinction are still largely unclear. Recently, new findings of elk bones were made in or close to the Bavarian Alps. They were found at two different localities, a pit cave named Stiefelschacht and a rivulet bed deposit. In particular, the findings of skeletal parts in the pit cave close to Lenggries are remarkable as they show traces of human hunting and butchering. These findings could provide new insights into potential causes of elk extinction in southern Bavaria and could contribute to the question of whether the Holocene elk population decline was triggered by humans. Here, we present osteological investigations on the elk bones including a detailed study of hunting and butchering traces as well as the stratigraphic context of the elk remains. The accompanying fauna and the pollen composition in the cave sediments were also studied. In addition, radiocarbon investigations allow a precise dating of the finds.

Based on these results we aim to elucidate (1) the habitat and palaeoecology of elk in the Bavarian Alps, (2) contribute to the distribution record of elk in the region, and (3) provide a better understanding of possible human hunting pressure causing an elk decline during prehistoric times.

\section{Sites and findings}

Elk bones were found recently at two different localities in or close to the Bavarian Alps and only about $20 \mathrm{~km}$ apart from each other (Fig. 1): (1) the finding of an antler by playing children in a rivulet bed near Heubach, ca. $1.5 \mathrm{~km}$ north of the village Bad Heilbrunn in the Bavarian Alpine foreland (Fig. 2), and (2) a partial skeleton found together with other bone remains by a private person in a pit cave in the Bavarian Alps, ca. $9 \mathrm{~km}$ south-south-east of Lenggries. While the first location did not provide a stratigraphic context, the findings at the second site come from cave sediments that were, however, partly disturbed previously. During a rescue excavation in October 2018, the remaining profile could be documented, and all animal bones were secured for further studies. The cave findings are meanwhile curated at the federal agency Landesamt für Denkmalpflege (BLFD), and the antler from Heubach is curated at the local museum in Bad Tölz (Heimatmuseum).

\section{Material and methods}

\subsection{Cave location}

Stiefelschacht is a small cave of $10 \mathrm{~m}$ overall length, comprising a $6 \mathrm{~m}$ deep vertical entrance pit and a $4 \mathrm{~m} \times 2 \mathrm{~m}$ wide chamber below (Fig. 3a, b, c). This cave is listed in the Bavarian Speleological Register under catalogue number $1276 / 7$. The pit entrance is located at $1136 \mathrm{~m}$ a.s.l. at $47^{\circ} 37^{\prime} 18^{\prime \prime} \mathrm{N}, 011^{\circ} 38^{\prime} 35^{\prime \prime} \mathrm{E}$ (WGS 84), ca. $100 \mathrm{~m}$ south of the saddle (1180 ma.s.l.), between the mountains Breitenkopf (1341 m a.s.l.) and Saurüsselkopf (1364 m a.s.l.), at the beginning of the Imbhäuselgraben ravine that drains south towards the village Glashütte. The entrance is marked on the Geological Map 1:25000 of sheet 8335 Lenggries (Doben, 1991), within folded Upper Triassic units of Norian age. The roughly west-east-extending mountain range corresponds to the strike of the folding and is built by massive dolomitic rocks (Hauptdolomit unit) overlain by bedded carbonates of the Plattenkalk unit. The cave is developed within thickbedded layers of the Plattenkalk unit.

An up to $170 \mathrm{~cm}$ high stratigraphic profile in the undisturbed remaining part of the debris cone was documented and sampled in $10 \mathrm{~cm}$ slices. These samples were split for geochemical and pollen analyses as well as for micro-vertebrate extraction.

\subsection{Geochemical analyses}

Samples from the profile were freeze-dried and thereafter sieved with $250 \mu \mathrm{m}$ mesh width. The fine fraction was used for geochemical analyses. Total carbon (TC) and total nitrogen (TN) were analysed with an elemental analyser (vario EL cube, Elementar) at the Institute of Geography, University of Erlangen-Nürnberg. For TOC determinations, sediment samples were weighed into crucibles and thereafter heated for $4 \mathrm{~h}$ at $550^{\circ} \mathrm{C}$ (Heiri et al., 2001). After heating, the weight loss was determined and the organic-free samples were used to 


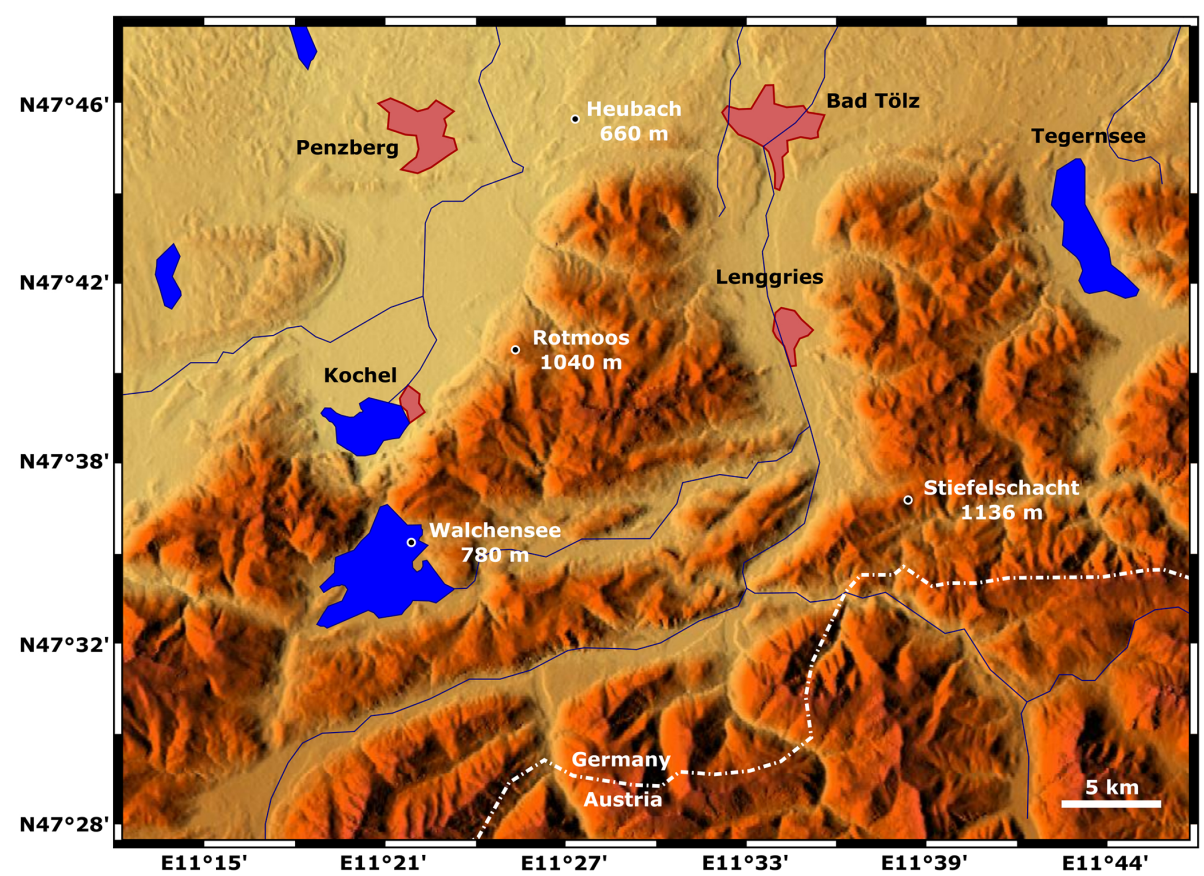

Figure 1. Map of the mentioned sites in the Bavarian Alps in southern Germany. Elk (Alces alces) bones were found at $25 \mathrm{~m}$ water depth in Lake Walchensee at $780 \mathrm{~m}$ a.s.1., in the pit cave 1276/7 Stiefelschacht at $1136 \mathrm{~m}$ a.s.1., and in the foreland in a small riverbed at Heubach at $660 \mathrm{~m}$ a.s.l. The pollen record of the Stiefelschacht cave is compared to the Late Holocene pollen record of Rotmoos at $1040 \mathrm{~m}$ a.s.1. The base map has been made with https://maps-for-free.com/ (last access: 1 May 2020); shaded reliefs are based on the Shuttle Radar Topography Mission satellite digital elevation model (DEM), released under Creative Commons CC0.

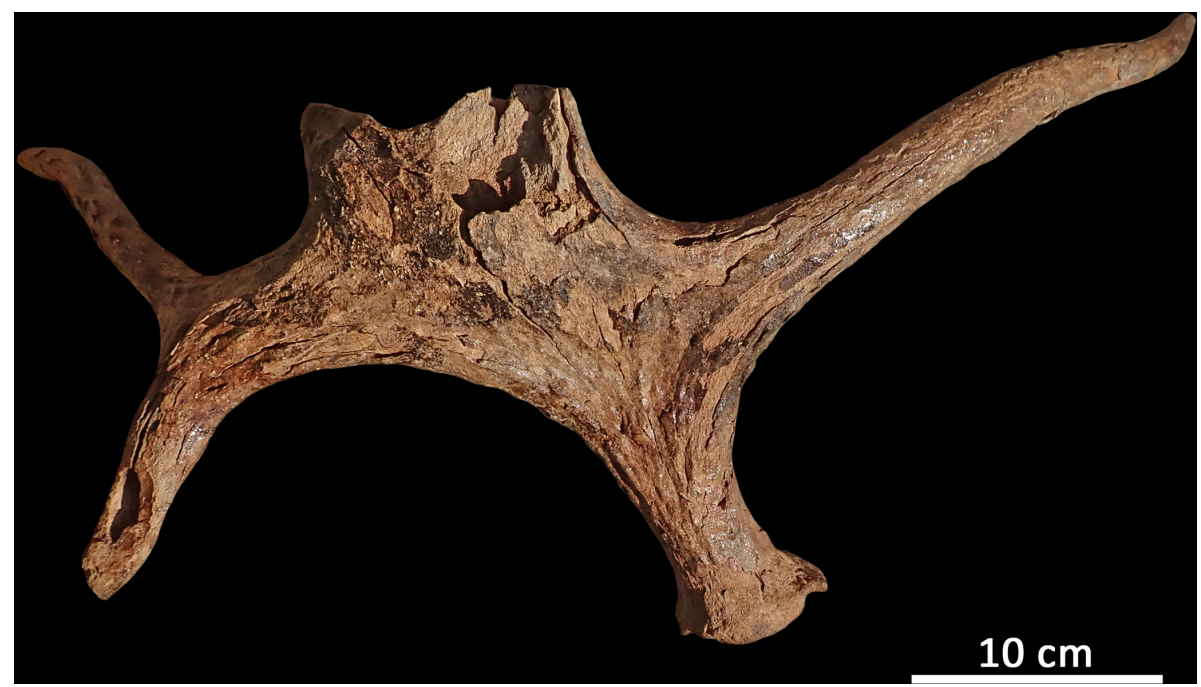

Figure 2. Fragment of elk antler from Bad Heilbrunn, Germany.

determine total inorganic carbon (TIC) with the device mentioned above. The difference between TC and TIC represents the total organic carbon content (TOC). All TOC/TN ratios are given as atomic ratios.

\subsection{Pollen analyses}

A total of $2 \mathrm{~mL}$ of fine material was taken with syringes of each $10 \mathrm{~cm}$ sample and stored cool $\left(4^{\circ} \mathrm{C}\right)$ until further processing. A total of 10 samples for pollen analyses were prepared at the University of Cologne following standard palynological techniques (Faegri and Iversen, 1989). Pollen grains were identified under $400 \times$ and $1000 \times$ magnifica- 

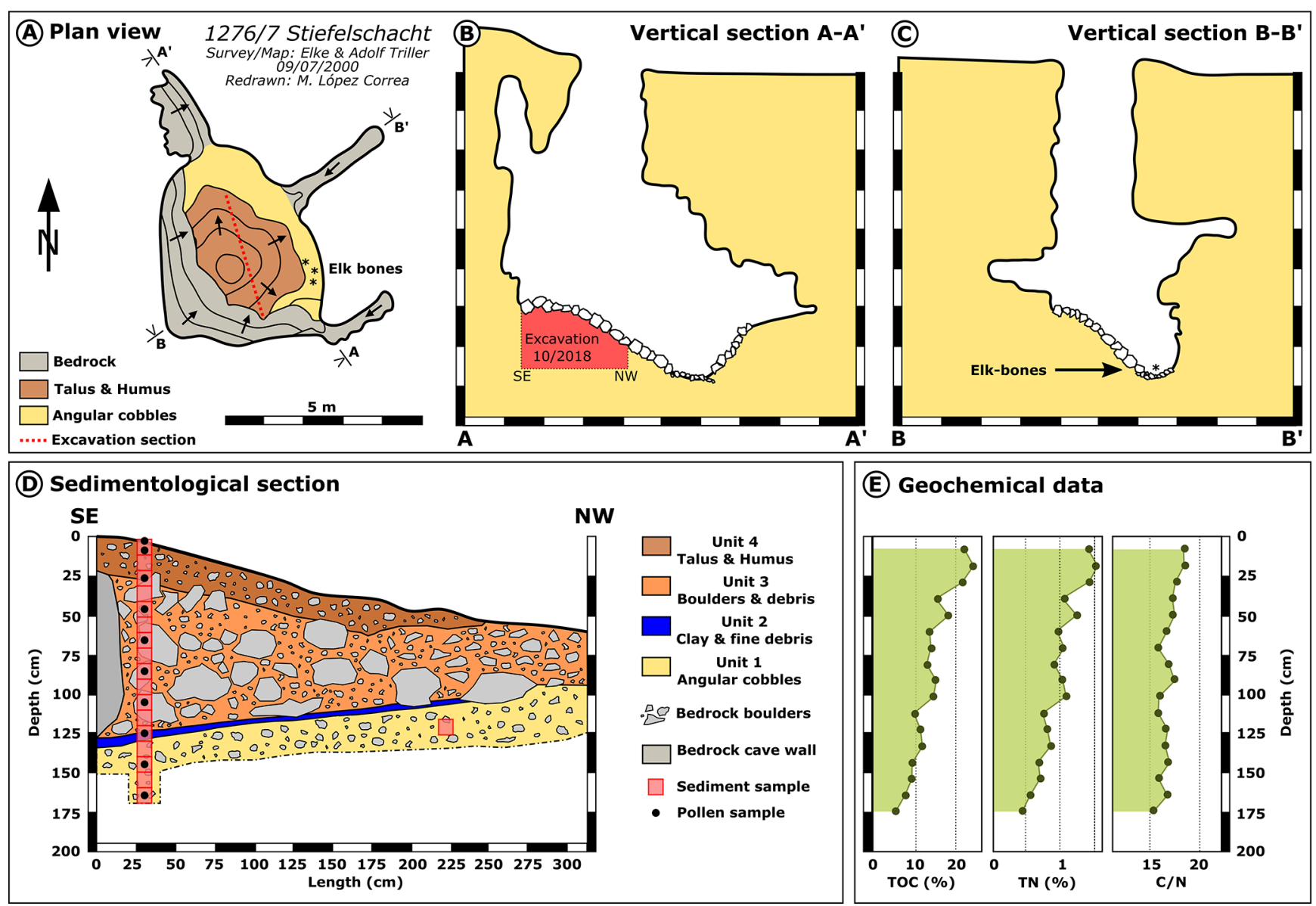

Figure 3. Simplified (a) plan view and (b, c) vertical cross sections of the cave 1276/7 Stiefelschacht, with the extent of the excavation and position of the stratigraphic section. The cave has been mapped by Elke $(\dagger)$ and Adolf Triller on 9 July 2000; Adolf Triller kindly provided the unpublished survey, which has been simplified and redrawn for publication with his permission. (d) The sedimentological section of the excavation carried out in October 2018. Unit 1: basal layer with small angular cobbles (beige); Unit 2: fine clay- and silt-rich cobble layer containing the elk bones (dark blue); Unit 3: coarse and loose block layer (orange-brown); Unit 4: finer surficial block layer with increased humus content (dark brown). Bedrock cave wall (dark grey) is present at the SE margin of the talus cone. All units contain bedrock-derived boulders of varying sizes (light grey). Boxes (red) mark the positions of sediment samples and geochemical samples, and black circles mark pollen samples taken within the $170 \mathrm{~cm}$ stratigraphic section. (e) Geochemical composition of the talus cone sediment samples with TOC (\%), TN (\%), and $\mathrm{C} / \mathrm{N}$ compositions.

tion using the reference collection at the Institute of Geography in Augsburg and the pollen key of Beug (2004). Pollen sums were calculated on the basis of the terrestrial pollen grains excluding Cyperaceae, spores, and indeterminata. Pollen nomenclature follows Beug (2004); spores are named according to Reille (1998). Due to the low pollen concentrations, three entire slides were counted except of the uppermost sample, in which a pollen sum of $>400$ was reached after one slide.

\subsection{Radiocarbon dating}

At least $1 \mathrm{~g}$ of bone material was sent to the radiocarbon labs in Poznan and Belfast for radiocarbon dating of the extracted bone collagen, which is routinely quality-checked by $\mathrm{C} / \mathrm{N}$ determination. Radiocarbon ages $\left({ }^{14} \mathrm{C}\right.$ years $\left.\mathrm{BP}\right)$ were calibrated with the software Calib REV7.1.0 using the IntCal 13 calibration dataset (Reimer et al., 2013). Dates are reported as calibrated ages (cal BCE or CE) with their $2 \sigma$ probability ranges and median probability.

\subsection{Osteoarchaeological methods}

After the excavation of the complete cave filling, the osteological material was taxonomically identified. Every single fragment was recorded in the computer program OssoBook (Kaltenthaler et al., 2018). Bones and teeth were measured with a digital calliper following the instructions by von den Driesch (1976). Traces of manipulation by humans were assessed macroscopically and documented photographically by 
using a Nikon D5100 in combination with an AF-S Micro NIKKOR $40 \mathrm{~mm}$ adapter. At the University of Hildesheim, a reflected-light microscope was used to assess the shape of the cuts. At the University of Erlangen-Nürnberg (GZN) the cut marks have been photographed with a SmartZoom 5 automated digital microscope with a PlanApo D $1.6 \times$ objective $(36 \mathrm{~mm}, 0.1 \mathrm{~mm}$ fixed working distance, FWD). Photo stacks were acquired with $15 \mu \mathrm{m}$ step size with up to 170 images and then processed with the ZEISS SmartZoom 5 software to stitch extended-depth-of-field (EDF) images into high-resolution mosaics.

The coarse fraction $(>250 \mu \mathrm{m})$ of all sediment samples from the $170 \mathrm{~cm}$ stratigraphic section was also screened for micro-vertebrates to complement the environmental reconstruction from pollen data and geochemical analyses.

\section{Results}

\subsection{Stratigraphy}

The single concealed cave room has a flat floor of fine rock debris with a silty matrix. This sediment also forms the basal Unit 1 encountered in the excavated sediment stack. During the excavation in October 2018 , a $310 \mathrm{~cm}$ wide section could be prepared within the sediment cone exhibiting the internal stratigraphy with a maximum thickness of $170 \mathrm{~cm}$ (Fig. 3d). Above the flat-lying basal Unit $1(170$ to $130 \mathrm{~cm}$ below cave surface in the sampled profile) consisting predominantly of angular cobbles, a thin layer follows made of finer rock debris with a silt- and clay-rich matrix (Unit 2, 130 to $125 \mathrm{~cm}$ ), which, according to the finder, corresponds to the stratigraphic level of the elk bones and is likewise subhorizontal. Unit $3(125$ to $30 \mathrm{~cm})$ comprises a layer forming a talus consisting of coarse angular to subangular blocks, which were loosely packed in a humic, silty matrix. The upper boundary of this layer is around $20^{\circ}$ declining toward the north-west (Fig. 3d). The youngest unit, Unit $4(30$ to $0 \mathrm{~cm})$, is also part of the talus but comprises smaller blocks and a more humic-rich matrix, and its surface is also inclined $20^{\circ}$ away from the entrance pit. This most recent layer contains glass shards, pieces of plastic and rusty metal, wood logs, and leaf litter.

Skeletal parts of smaller animals (hare) in anatomical order and a few disarticulated bones of larger animals were found during the excavation in stratigraphic Units 2, 3, and 4. The majority of larger mammal bones were found prior to our excavation and could thus not be attributed to stratigraphic units. An exception are the remains of the adult elk. According to the finder, these were found at the base of the talus, assigning them to Unit 2. From a top view, the elk bones were located not in the centre of the talus cone but at its eastern margin (Fig. 3a), explaining why they were covered, according to the finder, by only thin talus sediments compared to the thick layer in the excavated section directly below the shaft entrance.

\subsection{Geochemical analyses}

TOC (\%), TN (\%), and $\mathrm{C} / \mathrm{N}$ data show a steady decrease from the humic surficial layers to the more carbonatedominated basal sediments (Fig. 3e). TOC decreases from more than $20 \%$ in surficial Unit 4 to $7 \%$ in basal Unit 1 . TN content decreases from $1.4 \%$ at the surface to $0.4 \%$ at the base of the section, whereas $\mathrm{C} / \mathrm{N}$ ratios slightly decrease from 18.3 to 15.2 .

\subsection{Pollen analyses}

In the lowermost two samples (Unit 1 in Fig. 3), arboreal pollen taxa (AP) occur with abundances around $60 \%$ (Fig. 4). The four samples between 125 and $65 \mathrm{~cm}$ (Unit 2 and lower part of Unit 3) are characterized by poor pollen preservation. Cichorioideae and Polypodiaceae are both palynomorphs that are highly resistant to corrosion (e.g. Bottema, 1975; Groner, 2004), and they are enriched and accompanied by higher frequencies of deteriorated pollen counts, which were not further identifiable. As a consequence, AP decrease. From ca. $45 \mathrm{~cm}$ onwards (upper part of Units 3 and 4), pollen preservation is comparatively well indicated by lower values of Cichorioideae and Polypodiaceae. In turn, AP reach higher values (mainly Fagus sylvatica, Picea abies, and Alnus glutinosa-type). Cultural indicators, such as $\mathrm{Se}$ cale cereale, Plantago lanceolata, and Chenopodium, are registered from $150 \mathrm{~cm}$ upwards, pointing to human activity, while they are missing in the lowermost sample (170$160 \mathrm{~cm})$.

\subsection{Radiocarbon dating}

The dating result of the adult elk from the pit cave is shown in Table 1. The vertebra cervicalis dated from the elk partial skeleton found in the pit cave Stiefelschacht has a Late Holocene median age of $287 \mathrm{cal} \mathrm{BCE}$, dating it to the preRoman Iron Age, the La Tène period (approx. 450-1 BCE). Additionally, the antler from the rivulet bed close to Bad Heilbrunn was dated and has a Late Holocene median age of 997 cal BCE, corresponding to the Late Bronze Age (approx. 1300-800 BCE; Sommer, 2006).

\subsection{Macro-mammals}

The osteological material contained 690 bones (number of identified specimens, NISP) with a total weight of $21 \mathrm{~kg}$ (Table 2). The preservation of the bones was in most cases excellent. Two domestic and four wild mammalian species have been identified.

Among the wild ungulates and beside the elk (Alces alces) studied herein, red deer (Cervus elaphus) and roe deer (Capreolus capreolus) were present.

Hare remains were quite numerous. Two possible hare species, the European hare (Lepus europaeus) and Alpine hare (L. timidus), are difficult to distinguish by their skele- 


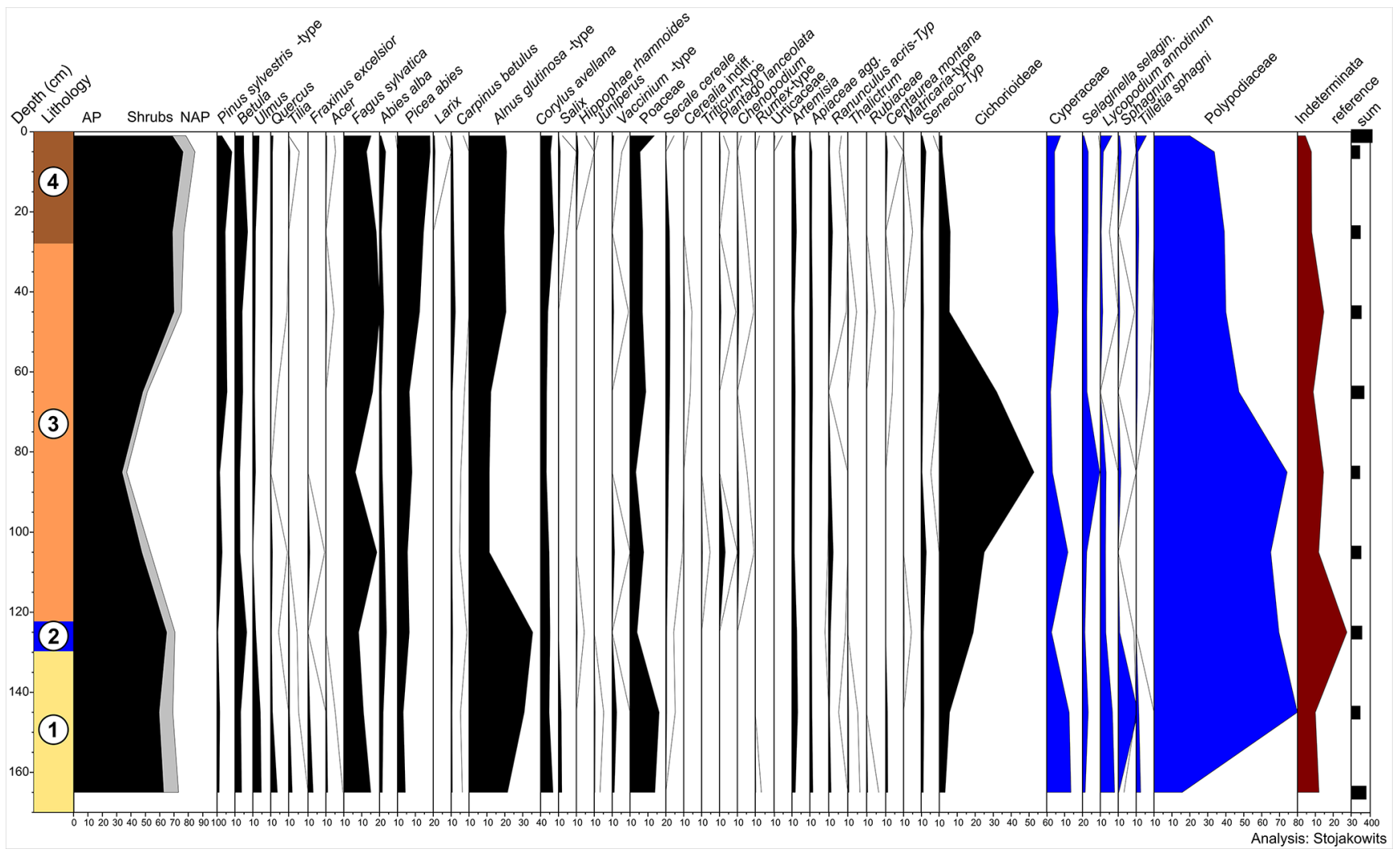

Figure 4. Late Holocene pollen record of the sedimentological section in the pit cave 1276/7 Stiefelschacht; numbers in the lithological column refer to units in Fig. $3 \mathrm{~d}$.

Table 1. Radiocarbon-dated elk finds from the Bavarian Alps mentioned in the paper.

\begin{tabular}{|c|c|c|c|c|c|c|c|}
\hline Sample & Locality & $\begin{array}{l}\text { Coordinates, } \\
\text { Altitude } \\
\text { (m a.s.l.) }\end{array}$ & Lab code & $\begin{array}{l}\text { Radiocarbon } \\
\text { age } \\
\left({ }^{14} \mathrm{C} \text { yr BP }\right)\end{array}$ & $\begin{array}{l}\mathrm{C} / \mathrm{N} \\
\text { ratio }\end{array}$ & $\begin{array}{l}\text { Calendar age } \\
\text { ranges }(2 \sigma)^{\mathrm{a}} \\
(\text { cal BCE) }\end{array}$ & $\begin{array}{r}\text { Median } \\
\text { probability } \\
\text { age (cal BCE) }\end{array}$ \\
\hline $\begin{array}{l}\text { Elk, } \\
\text { vertebra } \\
\text { cervicalis }\end{array}$ & $\begin{array}{l}\text { Stiefelschacht (pit cave), } \\
\text { ca. } 9 \mathrm{~km} \text { south-south-east of Lenggries; } \\
\text { in cave sediments }\end{array}$ & $\begin{array}{l}47^{\circ} 37^{\prime} 16^{\prime \prime} \mathrm{N} \\
11^{\circ} 38^{\prime} 34^{\prime \prime} \mathrm{E} \\
1136 \mathrm{~m}\end{array}$ & Poz-49753 & $2195 \pm 30$ & 3.5 & $\begin{array}{l}363-183 \\
(1.000)\end{array}$ & 287 \\
\hline $\begin{array}{l}\text { Elk, } \\
\text { antler }\end{array}$ & $\begin{array}{l}\text { Heubach, Bad Heilbrunn; } \\
\text { rivulet bed }\end{array}$ & $\begin{array}{l}47^{\circ} 45^{\prime} 40^{\prime \prime} \mathrm{N} \\
11^{\circ} 28^{\prime} 12^{\prime \prime} \mathrm{E} \\
660 \mathrm{~m}\end{array}$ & UBA-40211 & $2840 \pm 32$ & 3.3 & $\begin{array}{l}1109-1098 \\
(0.021) \\
1091-916 \\
(0.979)\end{array}$ & 997 \\
\hline $\begin{array}{l}\text { Elk, skull } \\
\text { fragment }^{b}\end{array}$ & $\begin{array}{l}\text { Hirschhörndl Peninsula, } \\
\text { Walchensee; on a rock in } \\
\text { ca. } 20-25 \mathrm{~m} \text { water depth }\end{array}$ & $\begin{array}{l}47^{\circ} 36^{\prime} 19^{\prime \prime} \mathrm{N} \\
11^{\circ} 21^{\prime} 50^{\prime \prime} \mathrm{E} \\
780 \mathrm{~m}\end{array}$ & Poz-37430 & $9780 \pm 50$ & 4.6 & $\begin{array}{l}9318-9172 \\
(0.998) \\
9163-9160 \\
(0.002)\end{array}$ & 9260 \\
\hline
\end{tabular}

${ }^{a}$ Calibration software: Calib REV7.1.0, calibration dataset: Intcal 13 (Reimer et al., 2013), probabilities of respective age ranges given in brackets.

b Data from Rößner and Mayr (2011).

tal elements and were hence specified as Lepus sp. (see Sect. 5.3). Among the domestic species, two ungulates have been identified: the cattle (Bos taurus) and the sheep (Ovis aries). Due to difficulties in the distinction of sheep and goat bones, the presence of goat (Capra hircus) cannot be excluded.

A calculation of the minimum number of individuals (MNI) for each large mammal species was also carried out (Table 2). The calculation was based on the most frequent 
Table 2. Species list of the macro-mammals of the pit cave Stiefelschacht close to Lenggries, Bavaria.

\begin{tabular}{lrrr}
\hline Species & NISP & Weight (g) & MNI \\
\hline Bos taurus (cattle) & 122 & 6154.4 & 3 \\
Bos taurus/Cervus elaphus & 2 & 13.9 & \\
Bos taurus/Cervus elaphus/Ovis aries/Capra hircus & 6 & 46.6 & \\
Ovis aries (sheep) & 10 & 321.6 & 4 \\
Alces alces (elk) & 73 & $11518.6^{\mathrm{a}}$ & 4 \\
Cervus elaphus ? $^{\mathrm{b}}$ (red deer) & 13 & 182.8 & 1 \\
Capreolus capreolus (roe deer) & 231 & 2469.4 & 10 \\
Indet., Mammalia, large size (size of cattle) & 2 & 4.4 & \\
Lepus sp. ${ }^{\mathrm{b}}$ (hare) & 231 & 376.6 & 8 \\
\hline Total & 690 & 21088.3 & 30 \\
\hline
\end{tabular}

a The cranium weight is included with an estimated $4 \mathrm{~kg} .{ }^{\mathrm{b}}$ Species classification; see discussion in Sects. 4.5 and 5.3. NISP: number of individual specimens; MNI: minimum number of individuals.

skeletal element and in consideration of the side, age, and sex. The MNI of roe deer attested 10 individuals, consisting of three adult males, two adult females, three juveniles, and two infants. The number of hare present in the pit cave was calculated to a minimum of eight individuals.

The red deer bones displayed a partial skeleton of probably only one deer individual, which was very young, maybe newborn. Although determined by using a comparative collection, Dama dama and Alces alces cannot be excluded with certainty due to the young age of the calf.

Elk were represented by a partial skeleton of an old bull (Table 3, Figs. 5, 6) and a few bones of very young calves (Fig. 6). Three pieces of right mandibulae of calves with identical age indicate the presence of three young animals. However, only small parts of the skeletons of these calves were found (about 12 bones). The skeleton of a large male elk is more complete, but the lower front legs, the lumbar part of the vertebrae, and both hind legs are missing (Fig. 7). Two additional elk bones (right scapula and right humerus) of the adult bull were not available at the time of determination.

Cattle were present, with remains of at least three individuals: one adult and two infants. The MNI of sheep was calculated to be four: two adults, one juvenile, and one infantile individual. All together an MNI of 7 domestic and 23 wild individuals could be attested.

Numerous skeletal elements exhibited cut marks. Cut marks were particularly frequent on the bones of the large elk bull. Cut marks could also be assessed on one elk calf bone, one cattle skeleton, one hare, and several roe deer bones. The left shoulder blade of the adult elk exhibited a hole, which was probably caused by a projectile (Fig. 8e).

\subsection{Micro-vertebrates}

Sediment samples across the $170 \mathrm{~cm}$ stratigraphic section, analysed for their pollen content and geochemical composition, also provided few bones of micro-vertebrates at all levels. Moreover, micro-vertebrates were also present in the bone collection that was not relatable to stratigraphic levels. Preliminary determinations show the presence of amphibians, rodents, insectivores, and further undetermined micromammals. The amphibians comprise frogs (Ranidae) and toads (Bufonidae). Insectivores are represented by the hedgehog (Erinaceus sp.), the mole (Talpa europaea), and the shrew (Sorex araneus) as the most common representatives. Rodents comprise murids and arvicolids.

\section{Discussion}

\subsection{Stratigraphy and geochemical analyses}

Stratigraphy and internal geometry of the sediments (Fig. 3) indicate a fast deposition of the talus deposits during the late Holocene, in line with the Holocene faunal content (Table 2) and pollen records. The decrease in TOC and TN from the cone surface (Unit 4) towards the basal layer of the cone (Unit 3) likely documents the effect of progressive degradation of organic matter. The decreasing $\mathrm{C} / \mathrm{N}$ ratios support this interpretation, which may indicate a rather young age of the talus cone (Enríquez et al., 1993). In contrast, the TOC, TN, and $\mathrm{C} / \mathrm{N}$ values of the lowest unit, Unit 1 , are rather uniform and point to a different sedimentation mechanism. The large number of decimetre-sized angular to subangular blocks inside the talus cone and the wood logs originally covering it were very likely deposited by human action, owing to the direct proximity to the forest road. The absence of blocks in the direct vicinity of the cave entrance, but not further apart, suggests that the blocks were collected and thrown by humans into the cave probably over a longer time period. The observations support the view that the talus was formed quite recently with the aid of humans present in the area. The dating of the elk at the base of the cone allows the age of the cone formation since the Late Iron Age to be narrowed down. 


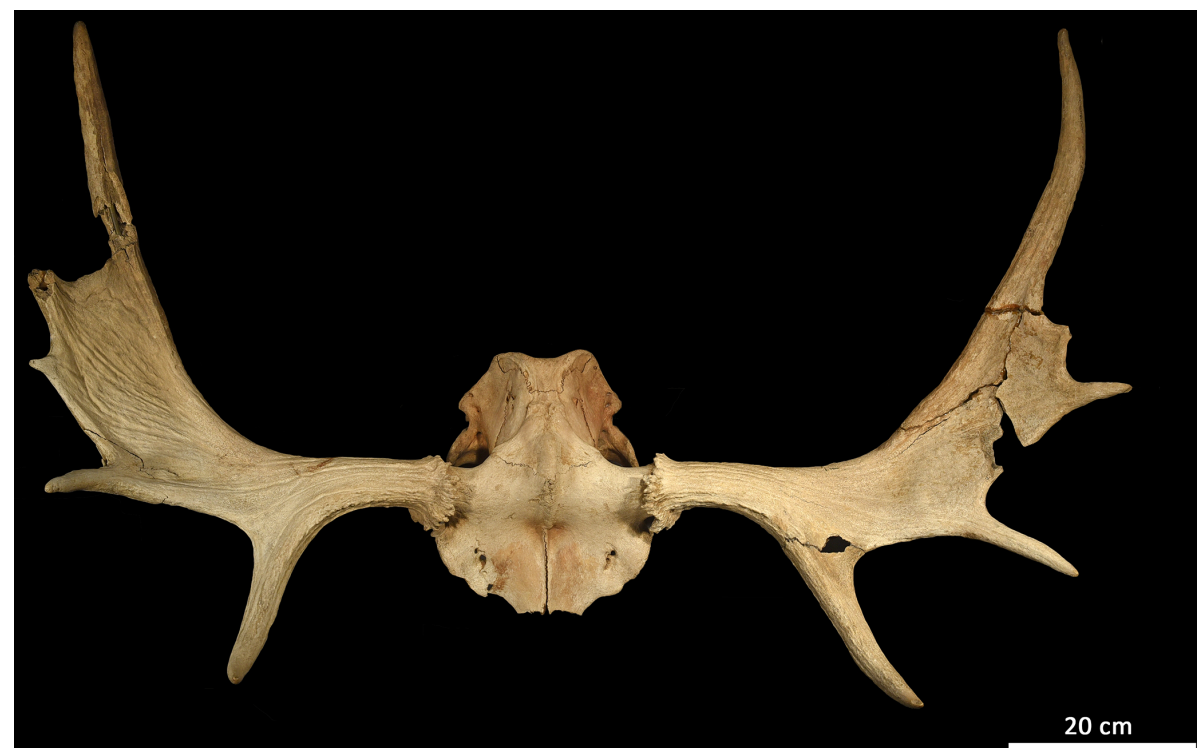

Figure 5. Elk (Alces alces) antlers found in the pit cave 1276/7 Stiefelschacht, belong to an adult male and a cervical vertebrate element of this individual has been radiocarbon dated to $2195 \pm 30{ }^{14} \mathrm{C}$ years $\mathrm{BP}$, corresponding to the La Tène period. (Photo taken by the authors.)

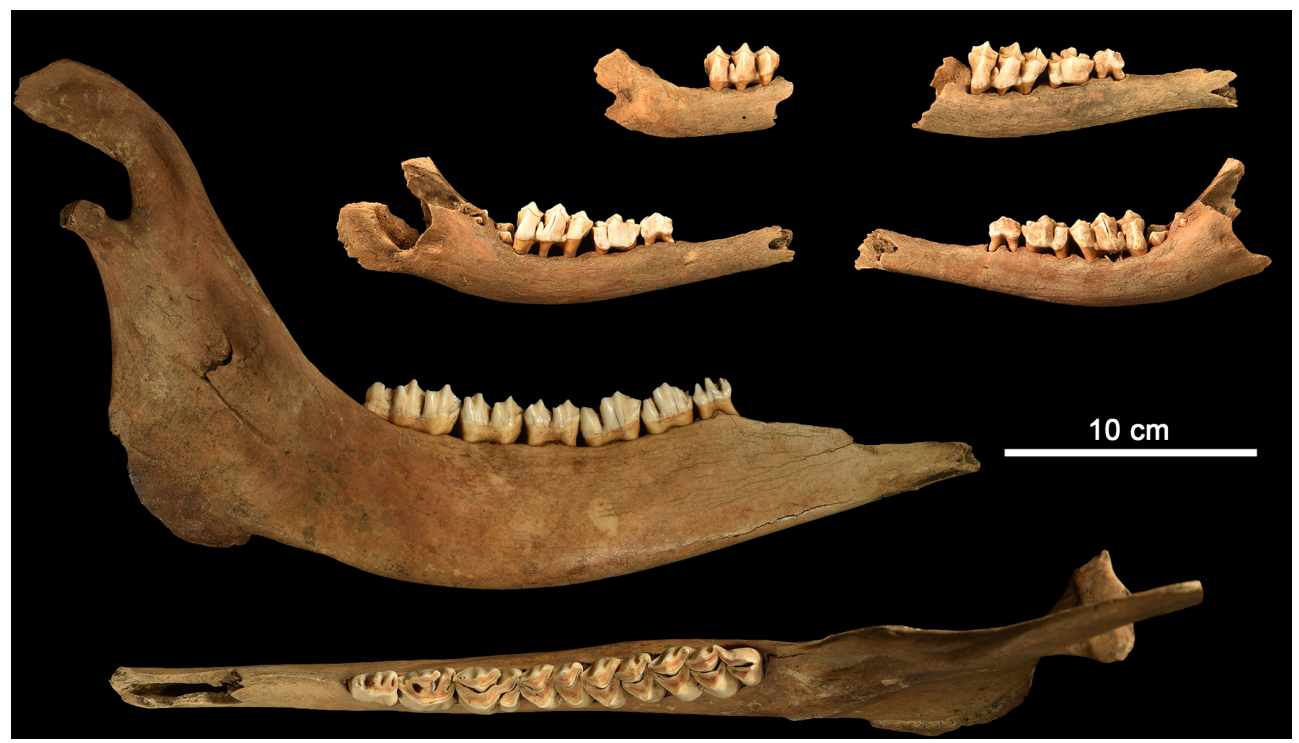

Figure 6. Overview on mandibular bones of elk (Alces alces) found in the pit cave 1276/7 Stiefelschacht. The mandibulae belong to one adult male and three juvenile individuals. All juveniles show the same ontogenetic stage with the same dentition where their first molar tooth is about to emerge. (Photo taken by the authors.)

\subsection{Pollen record}

Bludau and Görres (1993) investigated a pollen profile from the Rotmoos bog (Fig. 3) at 1040 m a.s.l., situated approx. $25 \mathrm{~km}$ north-west of the pit cave Stiefelschacht. There, mixed-montane beech forests with admixtures of Abies alba, Picea abies, and Acer pseudoplatanus have been prominent in the area since the Iron Age, confirmed by radiocarbon dating yielding an age of $399 \mathrm{BCE}$ to $125 \mathrm{CE}$ (recalibrated with IntCal13). Possibly due to differential preservation of paly- nomorphs, Fagus sylvatica is less frequent in the cave sediments than in the bog deposits. This taxon is more susceptible to corrosion than, for instance, Ulmus, which, in turn, is more sensitive than Betula and Alnus (Havinga, 1967). The palynological record provides further indications to constrain the age of the cave filling. The pollen interpretation is based on the assumption that infiltration of pollen through the talus sediment can largely be neglected. According to radiocarbon datings from the Ammergebirge (Bludau, 1985), Carpinus betulus was established at lower altitudes of the moun- 


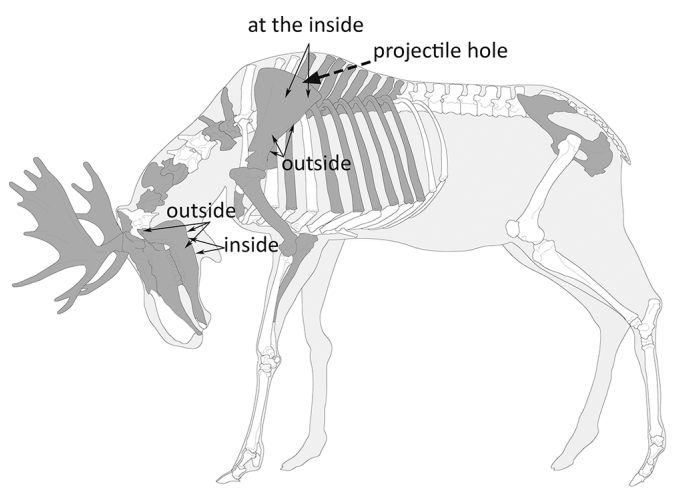

(A) Left body-side

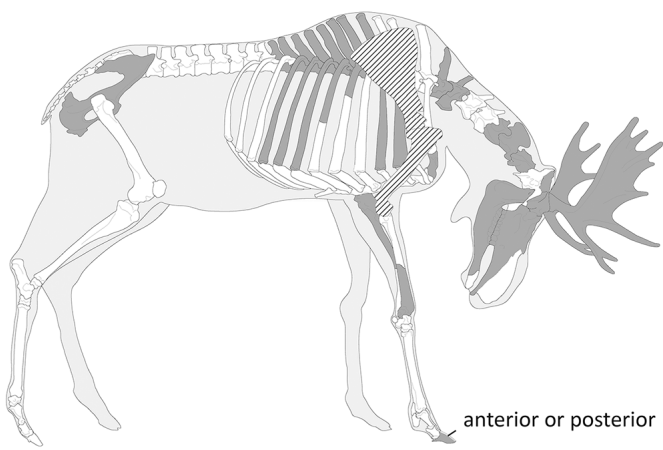

(B) Right body-side

Figure 7. Skeletal elements of the elk (Alces alces) bull which have been found in the pit cave 1276/7 Stiefelschacht marked in dark grey, separated by left-side (a) and right-side (b) elements with the position of cut marks indicated. The right scapula and humerus, which were excavated but not available for this analysis, are marked in light grey. The position and body side of the ribs are not precise. The "Élan" template is based on Coutureau (2013).

tain range during the Iron Age. Carpinus pollen is present in the entire cave section in small amounts. First single findings of Secale cereale occurred during the pre-Roman Iron Age (Bludau, 1985; Bludau and Görres, 1993) in the northern Calcareous Alps. Since the Middle Ages, this crop has continuously registered with low values $(<1 \%$; e.g. Bludau and Görres, 1993). Since Secale is present in small amounts in all but the lowest samples in the cave pollen record, the talus deposition started no earlier than the Iron Age.

\subsection{Faunal inventory}

All mammals found are common regional species throughout the Holocene. Only the adult elk can confidently be dated directly to the Late Iron Age based on the ${ }^{14} \mathrm{C}$ dating of one of its vertebrae. The only partly decomposed limbs of a roe deer (C. capreolus) found on top of the talus deposits in combination with modern waste material (glass, plastic) suggest that the cave was used as a dump by hunters until recent times. Roe deer has been a common species in the region since the Preboreal (Sommer et al., 2009).

As mentioned above (Sect. 4.5), the hare skeletal elements were determined as Lepus sp. In southern Germany, L. timidus was widely distributed only during glacial and early postglacial periods and occurs today only in high Alpine regions above $1300 \mathrm{~m}$ altitude (Thulin and Flux, 2003). Since the debris cone and the whole bone material therein were accumulated during the late Holocene, it is likely that the hare bones represent $L$. europaeus.

Among the micro-vertebrates, the insectivores (Erinaceus sp., Talpa europaea, Sorex sp.), the rodents (Muridae, Arvicolidae), and the amphibians, all constitute faunal components of the Holocene environment surrounding the cave. According to the pollen record, the vegetation was a mixedmontane beech forest throughout the whole profile, in which
Fagus sylvatica ranked among the most frequent dominant arboreal plants. Land snails were present but not identified in detail.

\subsection{Temporal and spatial context of the elk findings}

The new elk finding shall be briefly contextualized with other findings in the region in this chapter. Elk had occurred in central Europe and the northern Alps since Pleistocene times (Baales et al., 2002; Breda and Raufuss, 2016; Rosendahl et al., 2007; Spötl et al., 2013). A. alces was colonizing the central European lowlands during the Preboreal warming (Schmölcke and Zachos, 2005). In our study area, an elk skull fragment found at the lake bottom of Walchensee at a water depth of $20-25 \mathrm{~m}$ (780 m a.s.l., Fig. 1) was dated to the early Preboreal, although the rather high $\mathrm{C} / \mathrm{N}$ ratio of the dated collagen may challenge the validity of this age (Table 1; Rößner and Mayr, 2011). The finding from Walchensee indicates that elk occupied the Bavarian Alps already during the earliest stage of the Holocene.

Several findings of elk bones from caves and pit caves in the Austrian Alps were collected over decades. One of the most complete skeletons comes from the pit cave Vorderkarhöhle in the Karwendel region (Austria), around $20 \mathrm{~km}$ to the south of our cave site. It was excavated by locals in $1951 \mathrm{CE}$ at an altitude of $1848 \mathrm{~m}$ a.s.l. (Niederwolfsgruber, 1962). Other Alpine findings of elk in Austria originate from the Kammergebirge (Dachstein range), in which 10 pit caves at altitudes between $1560 \mathrm{~m}$ and $1805 \mathrm{~m}$ a.s.l. provided bones from prehistoric elk (Graf, 2014). Radiocarbon dating of bones from two of these sites provided median calibrated ages of ca. $1200 \mathrm{cal}$ BCE $\left(2980 \pm 30{ }^{14} \mathrm{C}\right.$ yr BP; Schönluegschacht) and ca. $1800 \mathrm{cal}$ BCE $\left(3470 \pm 30{ }^{14} \mathrm{C}\right.$ yr BP; Elchhöhle, Neubergsee; Graf, 2014). 
Table 3. Measurements in millimetres of the adult elk (Alces alces) skeletal elements (right side). Abbreviations after von den Driesch (1976) and OssoBook (Kaltenthaler et al., 2018).

\begin{tabular}{|c|c|}
\hline Skeletal element & Measurement \\
\hline \multicolumn{2}{|l|}{ Maxilla dentes } \\
\hline LMR (Alv) & 76.48 \\
\hline LPR P4-P2 (Alv) & 61.51 \\
\hline LM1 & 25.35 \\
\hline BM1 & 23.74 \\
\hline LM2 & 24.86 \\
\hline BM2 & 27.97 \\
\hline LM3 & 29.52 \\
\hline BM3 & 28.04 \\
\hline \multicolumn{2}{|c|}{ Mandibula/mandibula dentes } \\
\hline LChR M3-P2 (Alv) & 149.21 \\
\hline LM1 & 24.76 \\
\hline BM1 & 17.51 \\
\hline BM2 & 18.56 \\
\hline \multicolumn{2}{|l|}{ Atlas } \\
\hline GB & 145.09 \\
\hline BFcr & 168.85 \\
\hline BFcd & 169.96 \\
\hline \multicolumn{2}{|l|}{ Scapula } \\
\hline SLC & 54.23 \\
\hline GLP & 73.89 \\
\hline LG & 55.90 \\
\hline BG & 49.41 \\
\hline HS & 388.00 \\
\hline \multicolumn{2}{|l|}{ Humerus } \\
\hline $\mathrm{Bd}$ & 76.06 \\
\hline BT & 67.94 \\
\hline SD & 39.93 \\
\hline $\mathrm{Bp}$ & 91.26 \\
\hline $\mathrm{Dp}$ & 111.09 \\
\hline $\mathrm{LC}$ & 245.00 \\
\hline GL & 374.00 \\
\hline \multicolumn{2}{|l|}{ Ulna } \\
\hline DPA & 68.49 \\
\hline SDO & 65.76 \\
\hline BPC & 36.51 \\
\hline \multicolumn{2}{|l|}{ Pelvis/coxa } \\
\hline GL & 426.00 \\
\hline LA & 56.62 \\
\hline
\end{tabular}

The antler recovered near Bad Heilbrunn (660 m a.s.l.; Fig. 2) in the Alpine foreland dates to around $997 \mathrm{cal} \mathrm{BCE}$. It supports the presence of elk also in the Late Bronze Age in the study area. More remarkably, the age from the pit cave Stiefelschacht at $1136 \mathrm{~m}$ a.s.l., at around $287 \mathrm{cal} \mathrm{BCE}$, indi- cates that during the Late Iron Age elk remained present also in mountainous areas, for which we had hitherto no dated records from the Bavarian Alps.

The reasons for extinction of Alces alces in central Europe are a matter of debate. Reduction and fragmentation of habitats, husbandry, and an increasing human population were regarded as possible reasons for a progressive disappearance of the elk population in west-central Europe, while hunting may have accelerated its extinction (Schmölcke and Zachos, 2005). While our findings cannot contribute to the complex question of why elk finally became extinct in central Europe, they demonstrate that elk hunting took place not only in the lowlands but also in the northern Alps already during the $\mathrm{La}$ Tène period. Thus, hunting pressure since prehistoric times cannot be neglected as a possible factor contributing to the extinction of elk in the Alps.

\subsection{Historical and archaeological classification}

The pit cave Stiefelschacht is located close to a trade route, which was in use at least since the high medieval time (11th/12th century CE) until recently (Beumann and Schröder, 1987). Today, this mountain pass is known as Imbhäuselgraben and labelled as Ackner-Steig in an old land register which was in use in the first half of the 19th century. The path proceeds from the village Glashütte (900 m a.s.l.) in the south along a switchback through to a mountain saddle in the north. The village Glashütte in the valley of the river Weißenbach was historically known as the gateway of a wood drift to the village of Wildbad Kreuth in the eastern direction. Only some kilometres west of the village Glashütte, the Achenpass to Austria trends towards the opposite direction. Hence, the Stiefelschacht is located at the crossroad area of several Alpine routes, which were in use in the medieval and early modern times (Maier, 1995) and probably already in prehistoric periods (Lang, 2002).

Relatively little is known concerning the La Tène period in this area (Irlinger, 2002). Archaeological sites are located only at a larger distance to the Stiefelschacht. The nearest site is a settlement close to Weyern (district of Miesbach), about $30 \mathrm{~km}$ north of the cave. This is followed by a settlement at Nußdorf am Inn (district of Rosenheim), which is situated $40 \mathrm{~km}$ to the north-east. In the north-west direction hereafter, the settlement Hohenfurch (district of Weilheim-Schongau) follows, with about $60 \mathrm{~km}$ distance to the cave. The archaeological traces of the Stiefelschacht provide new evidence of human activities and represent hitherto the only evidence of elk hunting for the La Tène period in this mountainous area.

\subsection{Iron Age elk hunting}

Due to the fact that the cave is several metres deep and that its walls are steep, it is a natural trap for animals accidentally falling down. Additionally, the finder of the elk remains, Josef Wasensteiner from Lenggries, reported that hunters in 
the recent past occasionally disposed their hunting waste into the cave. The presence of cut marks on the excavated prehistoric bones indicates that at least those bones with traces of human activity were deposed by humans into the pit cave. Carnivore gnawing was hardly present, suggesting a fast deposition of the bones into the pit cave after the animal's killing. However, most bones were complete, and an intentional smashing, as is common for archaeological material, did not exist.

Although the cave was completely excavated, no archaeological artefacts were found. Only some obviously recent findings were excavated such as the abovementioned pieces of glass, rusty metal, and plastic material in the upper portions of the talus cone.

Despite the small cave size and the meticulous search for the bones of the adult elk, the skeleton remained incomplete. The incompleteness of many of the other skeletons proves that only parts of these animals reached the cave. A projectile impact hole in the left shoulder blade, cut marks, and scraping traces on the elk bones are clear evidence for human activity and are interpreted as evidence for local elk hunting during the Late Iron Age. The other bones with anthropogenic traces are not radiocarbon dated yet and can therefore also be of Iron Age origin but may also be younger, up to recent age.

Although the traces, which were identified as cuts and scraping marks, correlate to the anatomical places where meat is abundant and are quite common for similar archaeological material (Pasda, 2009; Moubarak-Nahara et al., 2014), a detailed investigation seemed to be appropriate to be sure that the lesions were caused by humans and not by animal activities or were lesions caused by the environment. Therefore, the traces were investigated by magnification using several methods. In the following, some cuts are described in detail. The triangular shape of a cut mark (Fig. 8f) at the shoulder blade (Fig. 8e) exhibits the lacking of bone material laterally. The edges are running obliquely to the centre of the depression. This indicates the use of a sharp-edged tool. A sharp line is visible in the centre, which is caused by the cutting edge of the tool. At the bone surface beside the depression, an increase in bony material is visible, which was caused by the extrusion of the material. This happened while the bone was still fresh and soft, probably soon after the death of the animal. Concentrations of adjacent cut marks are located at several areas at the hip bone (Fig. 8a). This was caused by a repeated exertion of force by a probably dull tool. Similar parallel cuts are visible at the lateral side of the maxilla (Fig. 8c, d). One cut mark exhibits sharp and vertical rims on both sides of the cut and a rather flat centre, which was caused by a tool with a broad cutting edge (Fig. 8b).

Likewise, the incompleteness of the skeleton provides further evidence for manipulation prior to the deposition of the remains into the cave. No indication for skinning can be seen (see Moubarak-Nahara et al., 2014), and there are no traces of separation of skeletal elements (see Pasda, 2009). However, the cut and scraping marks are predominantly on sections with a lot of meat. This leads to the assumption that the meat was removed from the bones prior to deposition. Some bones were missing, such as those of the lower back and the hind legs. Considering that all layers of the cave were excavated completely, these bones did not reach into the cave. In summary, it can be concluded that only some bone material was discarded after the meat was removed.

\subsection{Season of hunt}

Two species, the elk and the red deer, can give indications of a hunting season. The presence of newborn elk further facilitates a determination of the hunting season during the summer. Usually elks give birth to one or two calves and rarely up to three or four individuals (Nygrén, 1986). Based on the equal ontogenetic stage of all three juvenile individuals, it is possible that they were from the same litter. The array of deciduous teeth is typically complete at birth, and the M1 (first permanent molar) is emerging briefly thereafter. Considering that the M1 tips are breaking through the mandibular surface, and the M2 is still hidden inside the lower jawbone, they also make an assignment to the season possible. The emergence of M2 (second permanent molar) in the mandible does occur after 6 months in age. The calves were either newborns or just a few weeks old when they were killed. Since the elk mating season is typically between September and November, and the duration of pregnancy ranges between 226 and $246 \mathrm{~d}$ (Nygrén, 1986), the season of killing can hence be narrowed down to between early July and mid-August.

Most calves of red deer are born in May and June in Europe, and only a small portion is born in July (Bützler, 1986). As the bones of the red deer were from a very young individual, probably not much older than newborn, it is likely that hunting of both species, elk and red deer, occurred during summer months.

\subsection{How and why did the Iron Age elk bones get into the pit cave?}

The next questions to answer are how and why the bones got into the pit cave. Pasture economy has been proven to exist since the Bronze Age in many areas of the Alps (Graf, 2014), and it is conceivable that large predators generally would have been a threat for the grazing livestock and domestic animals. Predators, like wolves, are potentially attracted by the smell of the hunting leftovers, and to prevent this, a fast disposal of the elk remains after the hunt and the butchering would be reasonable. As a natural cleft was in the surroundings of the hunting place, it was probably quite effective to use it as a rubbish chute. The fact that only parts of the hunted adult elk were disposed into the pit cave can be explained with logistic actions. The bigger an animal is, the more difficult it is to transport. The smaller a 


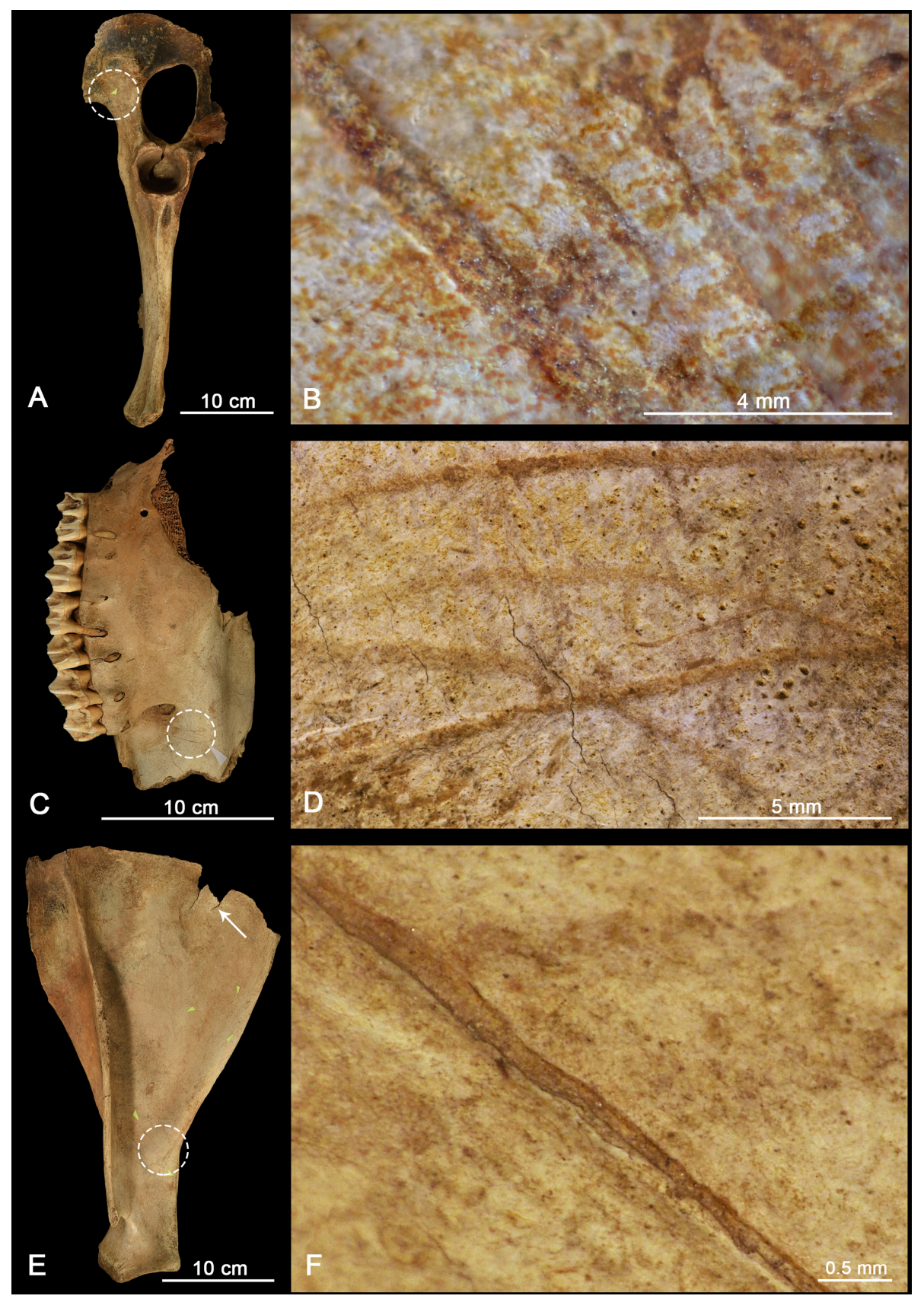

Figure 8. Documentation of characteristic cut marks on the elk bones (Alces alces) from the pit cave 1276/7 Stiefelschacht, showing (a, b) pelvic bone, $(\mathbf{c}, \mathbf{d})$ maxilla bone fragment, and $(\mathbf{e}, \mathbf{f})$ shoulder blade. The white circles on the bone overviews on the left side $(\mathbf{a}, \mathbf{c}, \mathbf{e})$ mark the position of magnified areas (b, d, f) of cutting traces attributed to Late Iron Age elk hunting. The arrow (e) at the scapula blade illustrates the position of a shot hole. (Photos taken by the authors.)

prey is, the larger the probability is that the complete hunted animal was transported into the residential area, which was, as previous research suggests, actually several tens of kilometres away. A large elk was simply too big and too heavy to be carried as a complete animal to the residential place. Therefore, it was important to carry as much meat as possible and that it was practically portable. In the case of the elk from the Stiefelschacht, some skeleton parts, such as the lower back and the hind legs, were absent. The lower back and the upper parts of the legs contain a lot of meat. The lower parts with the metapodials do not have a lot of meat but are quite functional for carrying the complete detached and heavy legs. This mode of transportation could be seen in Greenland, where the hunters carried the legs of the hunted 
caribou in that way to transport the meat to their camp sites (Pasda, 2009). The cut marks at the meat-rich bones indicate that only there the meat was detached and taken along with the purpose of reducing the weight for the transport. The remains which were left over were discarded into the cave.

\section{Conclusions}

The results presented here allow us to draw the following conclusions:

1. New findings are evidence that Alces alces was present in the northern Alps of Bavaria at least from Preboreal times to the La Tène period.

2. The incomplete skeleton of an adult and possibly also the remains of three calves found in the Stiefelschacht cave near Lenggries (Germany) suggest an intentional deposition by humans.

3. The bones of the adult elk show traces of butchering in the form of cut marks, providing the first evidence for elk hunting during the La Tène period in the northern Alps.

4. Despite missing direct archaeological evidence in a radius of less than $30 \mathrm{~km}$, the finding proves that the area around the cave has been frequented by humans since the La Tène period. Already at that time humans had an interest in removing hunting remains for unknown reasons.

5. Hunting pressure since prehistoric times has to be considered as a potential factor for elk extinction in the northern Alps.

Data availability. All relevant data are presented in the tables of the article.

Author contributions. KP, MLC, and CM wrote the original draft, which was complemented, reviewed, and edited by all authors. MLC, NaF, CM, and KP visualized the data and findings. $\mathrm{CM}$ and $\mathrm{BH}$ carried out the field work. PS carried out the pollen analysis and interpretation, and JP conducted the micro-mammal analysis. BH provided the archaeological context.

Competing interests. The authors declare that they have no conflict of interest.

Acknowledgements. We are grateful to Josef Wasensteiner (Lenggries), the finder of the elk bones, for drawing our attention to the cave site and for making his findings available as well as for logistic help in the field. We also thank Rudi Kornbichler, Martin Trappe, and Bernhard Keim for help with fieldwork and Daniela
Plötz, Bettina Goß, and Roland Wanninger for geodetic field surveys. G. Rößner is acknowledged for support and discussions in the initial phase, and Ute Schmidt and Austin Rettinghouse are acknowledged for assistance with geochemical analyses. A heartfelt thanks goes to Carsten Witzel, Horst Kierdorf, and Uwe Kierdorf, Institute of Biology, University of Hildesheim, for the opportunity to use their facilities. Bärbel Vogel, Werner Vogel, and Andreas Wolf from the German Speleological Society are thanked for discussions. Adolf Triller kindly provided the base map of his cave survey in the year 2000. The Bavarian Speleological Registry provided cave descriptions with background information, and we are indebted to Thomas Beilner. Amphibian identification benefited from the kind help of Davit Vasilyan (Porrentruy). This is CNRISMAR Bologna scientific contribution no. 2018. We also thank the anonymous reviewer.

Financial support. The article processing charge was funded by the Quaternary scientific community, as represented by the host institution of EGQSJ, the German Quaternary Association (DEUQUA).

Review statement. This paper was edited by Michael Zech and reviewed by Ulrich Schmölcke and one anonymous referee.

\section{References}

Baales, M., Jöris, O., Street, M., Bittmann, F., Weninger, B., and Wiethold, J.: Impact of the Late Glacial eruption of the Laacher See volcano, Central Rhineland, Germany, Quaternary Res., 58, 273-288, 2002.

Beug, H.-J.: Leitfaden der Pollenbestimmung für Mitteleuropa und angrenzende Gebiete, Pfeil, München, 2004.

Beumann, H. and Schröder, W. (Eds.): Die transalpinen Verbindungen der Bayern, Alemannen und Franken bis zum 10. Jahrhundert, Thorbecke, Sigmaringen, 1987.

Bludau, W.: Zur Paläoökologie des Ammergebirges im Spät- und Postglazial, Schäuble, Rheinfelden, 1985.

Bludau, W. and Görres, M.: Untersuchungen zur Siedlungstätigkeit des Menschen im süddeutschen Gebirge am Beispiel eines ombrogenen Moores - Pollenanalytische und geochemische Ergebnisse, Telma, 23, 213-236, 1993.

Bottema, S.: The interpretation of pollen spectra from prehistoric settlements (with special attention to Liguliflorae), Palaeohistoria, 17, 17-35, 1975.

Breda, M. and Raufuss, I.: Der älteste sicher einzustufende Fund des modernen Elchs Alces alces (LINNAEUS, 1758) in Mitteleuropa, Brandenburgische geowissenschaftliche Beiträge/Arbeitsberichte der Bodendenkmalpflege Brandenburg, 22/28, 175-182, 2016.

Bützler, W.: Cervus elaphus Linnaeus, 1758 - Rothirsch, in: Handbuch der Säugetiere Europas, Bd. 2/II: Paarhufer - Artiodactyla edited by: Niethammer, J. and Krapp, F., AULA-Verlag, Wiesbaden, 107-139, 1986.

Coutureau, M.: Élan (Alces sp.). Dessin Michel Coutureau, avec la collaboration de Julien Treuillot - 2013. D'après: Photographie du Muséum d'Histoire Naturelle de l'Université de l'Iowa, 
available at: http://www.flickr.com/photos/dfraryphotography/ 4012154129/in/pool-310353@N25/ (last access: 24 September 2015). Et d'après: Edmond Hue (1907) Musée Ostéologique. Étude de la faune quaternaire. Ostéométrie des Mammifères, Paris: Libraire C. Reinwald: Schleicher Frères, 2013.

Doben, K.: Geologische Karte von Bayern 1 : 25000 , Erläuterungen zum Blatt N. 8335 Lenggries, 125 pp., Bayerisches Geologisches Landesamt, München, 1991.

Enríquez, S., Duarte, C. M., and Sand-Jensen, K.: Patterns in decomposition rates among photosynthetic organisms: the importance of detritus C : N : P content, Oecologia, 94, 457-471, 1993.

Faegri, K. and Iversen, J.: Textbook of Pollen Analysis, John Wiley \& Sons Ltd., Chichester, 1989.

Graf, G.: Elchfunde im Kammergebirge, Schriftenreihe des Kammerhofmuseums Bad Aussee, 32, 20 pp., 2014.

Groner, U.: Palynology and sediment data from the high alpine karst cave on Jungfraujoch, Switzerland, Eclogae Geol. Helv., 97, 237-243, 2004.

Havinga, A. J.: Palynology and pollen preservation, Rev. Palaeobot. Palyno., 2, 81-98, 1967.

Heiri, O., Lotter, A., and Lemcke, G.: Loss on ignition as a method for estimating organic and carbonate content in sediments: reproducibility and comparability of results, J. Paleolimnol., 25, 101-110, 2001.

Irlinger, W.: Alpine und südalpine Funde der Eisenzeit in südbayerischen Fundkomplexen - ein Überblick, in: Über die Alpen - Menschen, Wege, Waren, composed by: Schnekenburger, G., Archäologisches Landesmuseum Baden-Württemberg, Theiss, Stuttgart, 183-190, 2002.

Kaltenthaler, D., Lohrer, J., Kröger, P., van der Meijden, C., Granado, E., Lamprecht, J., Nücke, F., Obermaier, H., Stopp, B., Baly, I., Callou, C., Gourichon, L., Pöllath, N., Peters, J., and Schibler, J.: OssoBook v5.6.2 München, Basel, available at: https://xbook.vetmed.uni-muenchen.de/, last access: 18 May 2018.

Lang, A.: Das Inntal als Route für Verkehr und Handel in der Eisenzeit. Über die Alpen - Menschen, Wege, Waren, composed by: Schnekenburger, G., Archäologisches Landesmuseum Baden-Württemberg, Theiss, Stuttgart, 49-57, 2002.

LWF: Bayerisches Staatsministerium für Ernährung, Landwirtschaft und Forsten, Bayerische Landesanstalt für Wald und Forstwirtschaft, LWF, available at: https://lwf.bayern.de/ biodiversitaet/wildtiermonitoring_jagd/078726/index.php (last access: 12 October 2020), 2011.

Maier, L.: Salzstraßen in Bayern. Salz macht Geschichte. Haus der Bayerischen Geschichte, edited by: Treml, M., Riepertinger, R., and Brockhoff, E., Pustet, Augsburg, 280-287, 1995.

Moubarak-Nahara, R., Castel, J.-C., and Besse, M.: Reconstructing carcass processing related to elk (Alces alces) exploitation during the Late Mesolithic: The case of Zamostje 2 (Central Russia), Quatern. Int., 337, 170-188, https://doi.org/10.1016/j.quaint.2014.04.057, 2014.

Niederwolfsgruber, F.: Elch-Skelett als Naturdenkmal, Natur und Land, 1, 18-19, 1962.

Nygrén, K. F.: Alces alces (Linnaeus, 1758) - Elch, in: Handbuch der Säugetiere Europas, Bd. 2/II: Paarhufer - Artiodactyla, edited by: Niethammer, J. and Krapp, F., AULA-Verlag, 173$197,1986$.
Pasda, K.: Connecting the present with the past: Traditional hunting methods and archaeozoological investigations in central west Greenland, in: Tracking down the past. Ethnohistory meets archaeozoology, Documenta Archaeobiologiae 7 (Jahrbuch der Staatssammlung für Anthropologie und Paläoanatomie München), edited by: Grupe, G., McGlynn, G., and Peters, J., Leidorf, Rahden, 81-102, 2009.

Reille, M.: Pollen et Spores d'Europe et d'Afrique du Nord, Supplement 2, Laboratoire de Botanique historique et Palynologie, Marseille, 1998.

Reimer, P. J., Bard, E., Bayliss, A., Beck, J. W., Blackwell, P. G., Bronk Ramsey, C., Buck, C. E., Cheng, H., Edwards, R. L., Friedrich, M., Grootes, P. M., Guilderson, T. P., Haflidason, H., Hajdas, I., Hatté, C., Heaton, T. J., Hogg, A. G., Hughen, K. A., Kaiser, K. F., Kromer, B., Manning, S. W., Niu, M., Reimer, R. W., Richards, D. A., Scott, E. M., Southon, J. R., Turney, C. S. M., and van der Plicht, J.: IntCal13 and Marine13 radiocarbon age calibration curves 0-50,000 years calBP, Radiocarbon, 55, 1869-1887, https://doi.org/10.2458/azu_js_rc.55.16947, 2013.

Rößner, G. E. and Mayr, C.: Altersdatierung des Elchschädels vom Walchensee BSPG, Jahresbericht 2010 und Mitteilungen der Freunde der Bayerischen Staatssammlung für Paläontologie und Historische Geologie München e.V., 39, 76-77, 2011.

Rosendahl, W., Döppes, D., and Kempe, S.: 30. MIS 5 to MIS 8 Numerically dated cave sites of Central Europe, Developments in Quaternary Sciences, 7, 455-470, 2007.

Schmölcke, U. and Zachos, F. E.: Holocene distribution and extinction of the moose (Alces alces, Cervidae) in Central Europe, Mamm. Biol., 70, 329-344, 2005.

Sommer, S. (Ed.): Archäologie in Bayern, Fenster zur Vergangenheit, Friedrich Pustet, Regensburg, Germany, 2006.

Sommer, R. S., Fahlke, J. M., Schmölcke, U., Benecke, N., and Zachos, F. E.: Quaternary history of the European roe deer Capreolus capreolus, Mammal Rev., 39, 1-6, 2009.

Spötl, C., Reimer, P. J., Starnberger, R., and Reimer, R. W.: A new radiocarbon chronology of Baumkirchen, stratotype for the onset of the Upper Würmian in the Alps, J. Quaternary Sci., 28, 552558, 2013.

Steiner, E.: Die Rückkehr des Elches (Alces alces L.) nach Österreich - Chronologie der Ereignisse, Stapfia, 37, 255-267, 1995.

Thulin, C.-G. and Flux, J. E. C.: Lepus timidus Linnaeus, 1758 - Schneehase, in: Handbuch der Säugetiere Europas, Bd. 3/II: Hasentiere, Lagomorpha, edited by: Niethammer, J. and Krapp, F., AULA-Verlag, Wiesbaden, 155-186, 2003.

von den Driesch, A.: A Guide to the Measurements of Animal Bones from Archaeological Sites as developed by the Institut für Palaeoanatomie, Domestikationsforschung und Geschichte der Tiermedizin of the University of Munich, Peabody Museum Bulletin 1, Peabody Museum of Archaeology and Ethnology, Harvard University, 1976.

Woodburn Hyde, W.: The curious animals of the Hercynian Forest, The Classical J., 13, 231-245, 1918. 